\title{
The Security Council's Crisis of Legitimacy and the Use of Force
}

\author{
Justin Morris $^{\mathrm{a}}$ and Nicholas J. Wheeler ${ }^{\mathrm{b}}$ \\ ${ }^{a}$ Department of Politics and International Studies, Faculty of Arts and Social Sciences, University \\ of Hull, Cottingham Road, Hull HU6 7RX, UK. \\ E-mail: J.C.Morris@hull.ac.uk \\ ${ }^{\mathrm{b}}$ Department of International Politics, University of Wales, Penglais, Aberystwyth SY23 3FE, \\ Wales, UK. \\ E-mail: njw@aber.ac.uk
}

The United Nations Security Council (UNSC) is at the heart of the world's collective security system. It is upon this body that rests 'primary responsibility for the maintenance of international peace and security' (UN Charter, Article 24). In this article, we examine the current debate regarding the legitimacy crisis facing the UNSC. We consider its most usual manifestation, namely that the Council faces a crisis of legitimacy because of its inability to constrain the unilaterally inclined hegemonic United States. But we also examine the converse argument that it is the whole UN collective security mechanism (rather than just the Council) that is in crisis. According to this, it is the failure to recognize the unique dangers immanent within the contemporary security environment and the inability of the UN security system to tackle these which is the cause of the current crisis of legitimacy. International society, this position continues, must acknowledge these, and vest in the hegemon the powers it requires in order to meet its global responsibilities. Acknowledging the implications of both of these positions, we argue that the resolution of the current crisis of legitimacy is to be achieved through a more expansive interpretation of the Security Council's extant powers, accompanied by a commitment on the part of the United States to reinvest in the multilateral machinery upon which global order is founded.

International Politics (2007) 44, 214-231. doi:10.1057/palgrave.ip.8800185

Keywords: legitimacy; use of force; Security Council; collective security; great powers

\section{Introduction}

The United Nations Security Council (UNSC) occupies a unique position in the regime governing the use of force in international politics. Two key principles underpin this regime: first, a ban on the individual use of force other than for purposes of self-defence (in the face of actual or imminent attack); and second, it is the responsibility of the UNSC to determine whether there exists a 'threat to international peace and security' (Article 39), a prerequisite to its 
authorization of the collective use of force to uphold 'international peace and security' (Article 42). It is upon the UNSC that, '[i]n order to ensure prompt and effective action by the United Nations', the organization's 191 members 'confer ... primary responsibility for the maintenance of international peace and security' (Article 24), and in so doing 'agree to accept and carry out [its] decisions ... in accordance with the present Charter' (Article 25). Crucially, however, action by the Council can only be taken with the assent of its five permanent, veto-bearing Members (P-5) (Article 27).

It is now a matter of historical record that during the years of the Cold War the UNSC was incapable of performing the collective security role prescribed for it by the Charter. During this period of its history Great Power antagonism served to prevent the Security Council from meeting its Article 24 obligations and a more limited UN contribution to the maintenance of international peace and security was provided only by the advent of its non-coercive peacekeeping role (White, 1993). Veto paralysis ensured that the organization remained effectively impotent in the face of major security crises, especially where these involved the interests of the Cold War protagonists as they invariably did. Instead, an uneasy great power peace was maintained by the more traditional mechanism of the balance of power, along with the emergence of nuclear weaponry and the concomitant logic of mutually assured destruction (MAD). While MAD's calamitous implications prevented direct Great Power conflict, the United States and the Soviet Union ranked high among the list of those who violated the UN Charter's prohibition of the use of force, and yet both invariably sought justifications for their actions in its provisions and principles.

With good cause such rationales were invariably dismissed as rhetoric. It is certainly true that both the United States and the Soviet Union sought to exploit to the very limit the Charter's vagaries, but neither mounted a direct normative assault on the UNSC's role as spelt out in the Charter. Moreover, with the end of the Cold War it was to the articles and underlying ethos of the UN - and the legitimacy which these were seen to bestow - that Washington turned in its search for international support for its liberation of Kuwait from Iraqi occupation in 1990. Little more than a decade later, however, it was the US' forcible overthrow of Saddam Hussein which brought into sharpest focus questions regarding the legitimacy of the UNSC.

\section{Competing Conceptions of the Crisis of Legitimacy}

In the introduction to this collection, Christian Reus-Smit defines an actor or institution as experiencing a crisis of legitimacy 'when the level of social recognition that its identity, interests, practices, norms, or procedures are rightful declines to the point where [the actor or institution] must either adapt 
... or face disempowerment' (Reus-Smit, this volume). In the immediate aftermath of the Cold War, as the UNSC became more active, questions regarding its legitimacy tended to focus upon its failure adequately to represent a UN membership which had almost quadrupled since the organization's founding (Fassbender, 1998; Morris, 2000). However, as disagreements between the P-5 emerged over the Kosovo crisis in 1998-1999, and even more significantly in relation to Iraq in 2003 , this debate was overshadowed by one regarding the criteria to be applied in determining the acceptable bounds within which states may have recourse to the use of force. It is an exploration of these issues, and the fundamental bearing that they have on the UNSC's legitimacy, that forms the principal focus of this article.

The argument that follows is presented in the form of two opposing positions. The first of these harbours concerns regarding the legitimacy of the UNSC, which it sees as being undermined by the Council's apparent inability to constrain great power use of force, particularly by the United States. This interpretation of the crisis of legitimacy is countered by an alternative understanding - proffered most notably by neoconservative forces in the George W. Bush administration - which focuses on the perceived inability of the existing UN regime to meet the challenges of contemporary global security (Frum and Perle, 2003; Kaplan and Kristol, 2003). Recognizing the United States as having a unique hegemonic role within contemporary international society, neoconservatives deride the existing collective security regime for impeding the United States as it seeks to fulfil the responsibilities that accompany its exalted status.

Both individually and collectively, all UN member states have the right under Article 51 of the Charter to use force in response to actual or imminent attack, but this ceases once the UNSC 'has taken measures necessary to restore international peace and security', and in no circumstances does the right extend to unilateral preventive action. By virtue of their permanent, veto-bearing membership of the UNSC, the great powers have a privileged role in granting such authorization, but this does not extend to them being granted the exceptional right to wage war unilaterally. The destructive potential of nuclear conflict during the Cold War necessitated such a constraint, but in a unipolar world threatened by the perils of global terrorism, the destructive potential of weapons of mass destruction (WMD), and the proliferation-bridge of conduit rogue states, advocates of this position argue that it is no longer fit for this purpose. It follows, according to this line of reasoning, that if international peace and security is to be maintained, today's hegemonic power, rather than being constrained as the first among equals, uniquely requires freer rein in using force in fulfilment of what the United States sees as its rightful role as the guardian of world order. So long as the UNSC serves as a brake on the ability of the hegemon to perform such a role, P-5 unanimity, on which its successful 
functioning depends, remains vulnerable to unilateral action. Viewed from this perspective, concerns regarding the Council's legitimacy are a mere symptom of a more fundamental crisis afflicting the legitimacy of the broader collective security regime of which it is part.

The two competing conceptions of the legitimacy crisis outlined above converge, therefore, in the view that the UNSC faces increasing disempowerment, but they diverge on the causes of this. For those who wish to preserve and strengthen the existing regime, it is the UNSC's inability to constrain the hegemon which is at the root of the crisis; for those who believe that the hegemon should be afforded the exceptional exemption from the rules governing the use of force, it is this very constraining nature of the regime more generally which constitutes the crisis. Which position is taken as to the underlying cause of the crisis will have a fundamental bearing on the key question as to whether the UNSC remains the exclusive body for deciding when the use of force is justifiable and, if not, where the residual authority for making such decisions lies. Those who seek to preserve the regime argue that the UNSC's exclusive authority must be maintained, even if this means inaction as a result of a failure to satisfy the Charter's voting procedures. For proponents of this position, it is procedural conformity that is at the heart of legitimacy, but this proceduralism is underpinned by the normative belief that observance of the Charter's rules provides the greatest potential for maintaining international peace and security. The alternative argument suggests a more flexible approach to this exclusivity question and, in its most extreme formulations, tenders a notion of legitimacy which privileges the attainment of substantive values over proceduralism. It is to these questions that we now turn.

\section{Contestations over the Legitimacy of the Collective Security Regime in the 21st Century}

This article, in the spirit of the collection, maintains that in essence legitimacy is something which has to be socially bestowed (Claude, 1966; Reus-Smit, 2004; Clark, 2005). In his introduction to this collection, Reus-Smit distinguishes between the 'social constituency of legitimacy' and the 'realm of political action'. This distinction is crucial to understanding legitimacy as a social phenomenon rather than as an attribute that actors can claim for themselves. As he elaborates, 'the critical thing that differentiates legitimacy ... is the necessity of social recognition. No action can be coherently described as legitimate if it is not socially recognised as rightful' (Reus-Smit, this volume). The 'social constituency' is the relevant arena an actor seeks to establish legitimacy in, and actors might succeed in legitimating their claims in one 
constituency while failing in others. But as Reus-Smit points out, what is crucial is that those seeking legitimacy establish congruency between this constituency and the political realm within which they seek to act. Where legitimacy is understood in these terms, it follows that a disjuncture between these two spheres is likely to manifest itself in a legitimacy crisis. In practice, this issue of congruence manifests itself in questions regarding the centrality of the UNSC to decisions pertaining to the use of force. Below, we explore these, focusing on Security Council practice since the end of the Cold War, culminating in a more detailed consideration of the cases of Kosovo and Iraq. These cases are salient to our argument because in both situations force was used in the absence of an explicit UNSC mandate, and yet those taking action nevertheless justified it as legitimate.

For issues relating to the use of force, the political realm will always be global, since the normative framework that regulates this aspect of international life will invariably have ramifications for future cases. This is the inescapable logic of a global collective security regime. However, with regard to conduct in the field of international peace and security, it is recognized that the securing of a consensus within a co-extensive social constituency is impractical given the size of the UN's membership, the diversity of views and interests therein, and the necessity of expeditious action. The procedures of the Charter provide, therefore, a surrogate social constituency - that is, the UNSC - in order to satisfy the test of congruence that this legitimacy challenge poses. Under the Charter it is the 15-state Council that makes decisions in this regard, with resolutions requiring nine affirmative votes and the casting of no veto for successful passage (Article 27). This voting procedure, designed to ensure firstly that the UNSC was not divided between the Great Powers, and secondly, that the views of the non-permanent members must always figure in deliberations, is a cardinal norm of the UN system (Goodrich and Hambro, 1949; Russell, 1958; Claude, 1984). It follows that the composition of the Council at any one time is irrelevant to its authority in judging the rightfulness of an action, provided that membership of the UNSC is determined in accordance with Article 23 of the Charter. Less tangibly, though just as unequivocally, Article 24 of the Charter requires that, 'in carrying out its duties ... the Security Council acts on [the Members'] behalf'. While this responsibility upon the Council does not extend to any procedural mechanism by which it can be held accountable to the wider membership and other organs of the UN, Council members evidently recognize the need to legitimate their individual and collective actions in terms of Charter norms (Henkin, 1979; Franck, 1990; Wheeler, 2000; Johnstone, 2003; Morris, 2005. See also Hurd, this volume).

For those who support the current regime - and believe that the Council remains the linchpin of the collective security order - it is conformity with the 
rules and procedures of the Charter that constitutes the most important source of legitimacy. From this perspective, there is no crisis for the actual regime, because its procedures provide the means by which congruence between social constituency and the realm of political action can be maintained. What is instead seen to be in crisis is the means which are placed at the disposal of the UN membership, namely the Council. For those who understand the legitimacy crisis as rooted in the inadequacies of the regime, what matters is that action is taken to maintain global security irrespective of social approval in a constituency congruent with the realm of political action. Securing legitimacy remains important, but this can be restricted to the actor's core constituency. This does not preclude the raising of legitimacy claims within wider international and world society, but the success of these is not deemed to be essential, and it may well be ambiguous as to whether these are for anything other than instrumental purposes.

The Bush administration best exemplifies this thinking in its most extreme form. It recognizes that the UNSC has a primary responsibility for upholding world order, but contests whether the Council is meeting this most onerous of obligations. Dissatisfied with the current Charter rules which restrict the right of self-defence to situations in which an attack has either occurred or is imminent, Washington seeks an extension of the right to cover situations in which the danger is yet to fully materialize. Such a change is necessitated, it is claimed, by the emergence of a new security environment plagued by the threats which emanate from 'rogue states' developing, and/or terrorist groups acquiring, WMD (National Security Strategy, 2002, 2006).

The radicalism of the proposal that force may be used to counter nonimminent threats could be tempered by its embedding in UNSC practice. A willingness on the part of the Council to intercede in the face of more distant threats would legally terminate any right to take action in self-defence and hence return any such conflict to the confines of the UN. To this extent, a more expansive interpretation of Article 39 which encompassed preventive war would appear to go a significant way toward placating US concerns. Against this one must bear in mind that, although the administration's publicly presented rationales for a new interpretation of the self-defence rule suggest that it would be open to all states, the wider political context of the debate, so strongly coloured by notions of American exceptionalism, generates fears that it would be for the United States alone to exercise such a right (Hassner, 2002; Barber, 2003; Jervis, 2006). Key elements within the Bush administration see this as both a special prerogative of the United States and its responsibility as global hegemon. Such a conviction is underpinned by a belief that rightful conduct, as enshrined in the universality of American values, is not dependent for its legitimacy on approval in the international social constituency (Kagan, 2004). 
A less radical version of this position suggests that a selective group of states, such as those that demonstrably satisfy liberal democratic credentials, may, despite its more circumscribed nature, serve as an appropriate social constituency for legitimizing the use of force. The suggestion here is that where the UNSC fails to authorize the use of force, liberal states have a responsibility to act to uphold global order, including in extreme cases through the preventive use of force. A good example of this 'new liberal interventionism' is Lee Feinstein and Anne-Marie Slaughter's contention that there is a 'duty to prevent' non-democratic states from developing WMD on the part of liberal states (Feinstein and Slaughter, 2004. For critical appraisals, see Buchanan and Keohane, 2004; Wheeler and Morris, 2006). This argument resonates with those liberal theorists and leaders who have championed amending the international legal order to permit states to use force to protect endangered peoples (Blair, 2004; Tesón, 2005). It is to a consideration of these arguments that we now turn.

\section{Legitimacy Claims over Kosovo and Iraq}

At the end of the Cold War, the UNSC authorized a number of Western-led military interventions aimed primarily at alleviating humanitarian distress. This reflected the UNSC's newfound proclivity to interpret Article 39 in a more expansive manner. The humanitarian sentiments which, to varying degrees, motivated these actions were, however, far from universally shared. Both within and outside of the Council, states were suspicious of their underlying motivations, the precedents they set, and the increasing ability of Western states to mould the chamber to their will (Wheeler, 2000; Chesterman, 2001). Nevertheless, Council endorsement tempered such concerns, especially on the part of non-Western governments that had not participated in the Council's deliberations. The limits of Council consensus in relation to this new humanitarian interventionism were demonstrated by the humanitarian crisis that developed in Kosovo. Faced with Russian and Chinese threats to veto, and the consequent inability to secure UN authorization, NATO was forced to contemplate intervention in its absence. The dilemma presented - to act in accordance with the procedures of the Charter and remain inactive, or breach the UN rules in pursuit of substantive concerns regarding violations of human rights - was resolved in favour of the latter. Although Russia, China and India condemned NATO's action as a breach of the Charter regime, the relative equanimity with which NATO's action was greeted by the majority of other members of international society bore testament to the extent to which the more expansive interpretation of Chapter VII had come to be seen as legitimate (Wheeler, 2000). 
There were also assertions that, far from it being NATO that should be held responsible for violating Charter norms, it was those who opposed action and thus forced extra-UN activity - that should be called to account. The opposition of veto-bearing members of the Council prevented the passage of a resolution authorizing intervention, but advocates of action maintained that it was NATO that enjoyed majority support both within the chamber and among the UN membership as a whole. The best evidence of this was the resounding defeat (by 12 votes to three) of a Russian-led resolution condemning the intervention. This reflected the fact that in the eyes of many members of international society, NATO's action was in conformity with the underlying normative purposes of the collective security regime, but that the voting requirements of the Charter were preventing the UNSC from living up to its responsibilities (Clark, 2003; Wheeler, 2004, 44-47).

It was for this reason that Kosovo raised questions regarding the 'reasonableness' of the threat by permanent members of the Council to exercise their veto power. The relative equanimity with which NATO intervention was met suggests that there is considerable credence to its claim to have enjoyed significant international support. If this is the case, then the unreasonable veto argument seems equally meritorious. It is not, however, without its weaknesses. Whatever the extent of their putative support, NATO member states never put the matter to the test through a vote in either the Security Council (prior to military action) or the General Assembly, and irrespective of how they may have fared had they done so, Council members are not expected in the absence of an authorizing resolution to act as delegates for the UN membership (though the Council as a whole acts on their behalf). What is more, the 'unreasonable veto' argument implies that the veto is only ever exercised capriciously, but as Simon Chesterman pointed out, Russia's threat to veto might have reflected genuine misgivings about the use of force (Chesterman, 2001, 221). Whatever the merits of the argument, what is important about the debate in the UNSC is that all the interlocutors relied on legal and moral arguments that were anchored in the normative framework supplied by the UN Charter (Johnstone, 2003).

It is the acceptance displayed during the Kosovo crisis that legitimacy claims must be articulated within, rather than in disregard of, existing normative frameworks that explains the different international response to the US-led invasion of Iraq in 2003. Insofar as action in Iraq was intended to rid Saddam Hussein's regime of WMD, possession of which was prohibited by previous UNSC resolutions, there is a significant similarity with the Kosovo case. Indeed, the principal justification employed by the United States, the United Kingdom and Australia (the key military contributors) focused on Iraq's noncompliance with existing Security Council resolutions, especially Resolution 1441 which the Council had unanimously adopted on November 8, 2002, and 
which found Iraq to be in 'material breach' of its obligations under previous resolutions (www.un.int/usa/sres-iraq.htm). However, the majority of Council members were strongly of the view that this resolution did not provide automatic authority for the use of force, and that it would be for the Council (and not individual member states) to decide whether Iraq was in breach of the provisions of Resolution 1441 (Blix, 2004, 73-97, 175-218, 237-249; Malone, 2006, 192-201). This position was rejected by Washington, London and Canberra, which argued that the Council's authorization to use force against Iraq for its invasion of Kuwait in 1990 continued to provide legality for the use of force 13 years later. This line of legal argumentation is not wholly without merit, at least insofar as it passes Thomas Franck's 'laughter test' by not exposing its proponents to 'shame and ridicule' (Franck, 1990, 55), but it failed to persuade the majority of international lawyers and was rejected by a large number of states at the UN. In their eyes, the circumvention of the Council's authority over Iraq represented the flouting of the key principle of the post1945 collective security system (Lowe, 2003, 865-869; Roberts, 2003; Evans, 2004, 67-69; Murphy, 2004; Sands, 2005, 174-203).

What do the cases of Kosovo and Iraq tell us about the current crisis of legitimacy affecting the existing collective security order? In both cases opposition to military action was premised, in the first instance, on the grounds that it violated the guiding principle of the UN collective security system, namely that force cannot be used (other than in the Charter defined situation of self-defence) in the absence of a UNSC mandate. This apparently proceduralist position is, as alluded to above, underpinned by a compelling normative logic; the preservation of international order. The Charter's voting procedures and the special majorities they require are not ends in themselves; rather they exist as the best means by which to secure the UN's cardinal norms of the non-use of unilateral force, non-intervention, and respect for the sovereignty and territorial integrity of member states. These norms provide the cornerstone of international order, most importantly among the Great Powers upon whose cooperation the prospects for order so crucially depend (Jackson, 2000).

Those who seek to defend NATO's unilateralism over Kosovo reject the proceduralist argument on the grounds it was the UNSC that was failing in its responsibility as guardian of international peace and security. Faced with the intransigence of veto-bearing UNSC members willing to thwart the demands of a majority of the Council, they claim that NATO, as a community of the world's leading liberal-democratic states, was a sub-optimal, but nevertheless sufficient, social constituency within which consensus needed to be secured (Clark, 2003). The validity of this claim rests on the controversial contention that NATO represented the moral aspirations and values of world society, and that this bestowed upon it the right to act - including through the use of force 
— in defence of these 'civilized' values. More radically, but in a similar vein, the Bush administration claims that it was the United States that acted responsibly over Iraq, when once again the UNSC was in dereliction of its duties. Unlike Kosovo, Washington could not secure a social consensus that stretched further than Congressional authority and the support of a few close allies, but nevertheless insisted upon the legitimacy of its actions. What underlies this arrogance of power is the belief that America is the indispensable guarantor of global order in a post-9/11 world in which the US believes itself to be uniquely imperilled. The logic of this position is that the disempowering of the UNSC has been brought about, not by the refusal of the hegemon to play by the rules, but by the Council's inaction in the face of situations that demand robust responses.

What is not in doubt is that the UNSC's inability to constrain interventionism in the cases of Kosovo, and especially Iraq, constitutes a form of disempowerment. The Council faces growing costs in terms of its authority, and risks increasing irrelevance if its already limited ability to 'exert ... a pull towards compliance' (Franck, 1990, 16) is further diminished. This was certainly the view of Michael Glennon who maintained with regard to Iraq that ' $[w]$ ith the dramatic rupture of the UN Security Council, it became clear that the grand attempt to subject the use of force to the rule of law had failed.' Indeed, he went so far as to assert that the UNSC's ability to exert compliance pull is, post-Iraq, so limited that in contemplating the use of force states consider only questions of prudence rather than legality, asking 'not whether it [is] lawful ... [but] ... simply ... whether it [is] wise' (Glennon, 2003, 16). Nevertheless, he overlooks how far those who choose to act outside of the Council must also factor into their strategic considerations both the costs of undermining an institution of which they are, in most cases, privileged members, and the more direct costs which result from their failure to secure a mantle of international legitimacy. In the case of Kosovo, both these costs proved to be relatively slight as the alliance was able quickly to move back into the multilateral fold. This stands in marked contrast to Iraq where the United States and its limited coalition of allies were unable to share the political costs or the economic and military burdens of the conflict and its aftermath (Malone, 2006, 222-251). What these contrasting experiences show is the progressively higher costs associated with increasing levels of incongruence between an actor's social constituency of legitimacy and its realm of political action. Given the huge material resources at its disposal, Washington is at present able to shoulder such costs, but they do nevertheless constitute a form of disempowerment and hence reduce its capacity to engage in global policing activities. Moreover, insofar as the status of hegemon requires social recognition in addition to material might, it can be argued that its ability to fulfil this role is itself in danger of entering its own crisis of legitimacy. The 
implication of the forgoing analysis is that almost all states, from the weakest members of international society whose continued existence is inextricably linked with the UN and its collective security regime, to the hegemonic United States, have a vested interest in resolving the interlinked crises of legitimacy that currently afflict international politics.

As the UN struggled to cope with the crisis over Iraq, the UN SecretaryGeneral used his 2003 address to the UN General Assembly to express his considerable disquiet regarding the sidelining of the Council. In a veiled reference to the US and its allies, he asserted that the doctrine of unilateral, preventive war 'represents a fundamental challenge to the principles on which, however imperfectly, world peace and stability have rested for the last fiftyeight years.' Fearful that such a notion 'if it were to be adopted ... could set precedents that [would result] ... in a proliferation of the unilateral and lawless use of force', Annan nevertheless implored UN members to 'face up squarely to the concerns that make some States feel uniquely vulnerable, since it is those concerns that drive them to take unilateral action.' In his now famous phrase, the Secretary-General warned that the UN had arrived at a 'fork in the road' at which its members must decide between the status quo and the adoption of radical change. They must not, he counselled, 'shy away from questions about the adequacy, and effectiveness, of the rules and instruments at [their] disposal ... none [being] more important than the Security Council itself' (Annan, 2003). It is to the strategies that might be best employed in negotiating the Secretary-General's 'fork in the road' that we now turn.

\section{Resolving the Crises of International Legitimacy}

The different understandings of the reasons for the UNSC's disempowerment might suggest that it is not possible to identify a remedy that can satisfy the concerns of both points of view. This, however, is not the case. The key to resolving the crisis requires that proponents of both positions recognize the untapped potential of the Charter, and utilize the flexibility which its drafters so wisely built into it over six decades ago. As noted above, both have strong incentives for attempting to do so. For those who perceive the crisis of legitimacy as lying in the UNSC's failure to constrain the US and its allies in their use of force, it is necessary to explore whether the existing collective security framework might be adapted to meet the new threats that so animate the Bush White House. For those who view the Council as ineffectual in meeting these dangers, what is required is greater appreciation of the possibilities of multilateral mechanisms. Hence, both sides in this legitimation contest must concede important ground, and the key to achieving such an accommodation lies in an expanded understanding of Article 39. 
In 1945, those responsible for drafting the Charter deliberately rejected the idea that a 'threat to international peace and security' was amenable to definition, choosing instead to vest in the UNSC the ability to judge situations and the threat they posed as they arose. The new realities of the security environment of the early 21st century further confirm the wisdom of the founding fathers in building flexibility into the potentialities of Council action. Faced with the spectre of nuclear proliferation and perhaps even terrorist groups armed with WMD, the key issue today is whether the UNSC has the authority to take preventive action to deal with threats which are yet to fully materialize (Evans, 2004, 76-77). The argument that the UNSC should interpret Article 39 to cover non-imminent threats was pressed most strongly by the Secretary General's High-Level Panel on Threats, Challenges and Change. The panel sought to accommodate the two different approaches to the legitimacy crisis discussed here by suggesting that, if 'those who are concerned about great power unilateralism demonstrate a willingness to fully realise the potential of the Charter, those who tend towards unilateralism may be reassured that the UN system can provide the necessary security guarantees' (United Nations, 2004).

This, of course, will only provide a foundation for resolution if those whose proclivities are to eschew diplomatic engagement and the views of the majority re-engage with the Charter mechanism. So long as they remain wedded to a notion of legitimacy that stresses moral absolutism and negates the need for broad social support, there can, in the absence of any shift in material power, be no prospect of resolving or ameliorating the crisis. Engagement in a genuine dialogue in pursuit of legitimacy that is accepted as being dependent on congruence between the social constituency and the political realm of action has to be recognized as a sine qua non. It will not suffice for either to engage in 'bargaining based on fixed preferences' but must involve "'true reasoning", in which actors seek a reasoned consensus on the basis of shared understandings, where each actor not only tries to persuade but is also prepared to be persuaded' (Johnstone, 2003, 453). So while the United States would be well counselled to embrace the dialogical position noted above, those who castigate it for its unilateralism should heed the words of the Secretary-General as to the importance of reassuring Washington that US security can be protected through multilateral mechanisms. Establishing a new consensus based on the recommendations of the High-Level Panel would result in a realignment of social constituency — which would now be re-established as the UNSC - with the realm of political action. This broadened conception of threat and newfound commitment to address it through collective UN action provides a legitimate mechanism for meeting the new security challenges of the 21 st century.

One critical obstacle to this grand bargain is whether the current and future US administrations can be reassured by the prospect of collective action under 
Chapter VII. The Bush administration's mindset over Iraq suggests that it, for one, placed little faith in this. Believing that the United States is threatened on an unprecedented scale by regimes and groups whose ideologies commit them to the destruction of American values, Washington considered it axiomatic that the emergency was too great to rely on existing multilateral mechanisms of security, especially the UN (Hassner, 2002; Hendrickson, 2002; Barber, 2003; Simpson and Wheeler, 2006). Whereas traditionally Great Powers were, by definition, the least vulnerable to attack, the most striking paradox today is that the most powerful state in the world - and the symbol of the prevailing conception of global order - perceives itself to be uniquely vulnerable. From this perspective, the vulnerability of the United States can be addressed only through policies of regime change, preventive war and national missile defence, and insofar as the UN system is incapable of delivering these, it has no choice but to act unilaterally. It is this which has led some commentators to argue that the 'depiction of the malady of the revolutionary power increasingly fits the United States' (Hendrickson, 2002, 9, emphasis added. See also Barber, 2003; Wheeler, 2005; Jervis, 2006). Such a state will, as Henry Kissinger famously opined, be beyond reassurance (Kissinger, 1977, 2) and will be more sensitive to potential threats and less tolerant of policies which delay remedial action. The danger, of which the High-Level Panel was all too conscious, is that those who cannot be reassured will be 'impatient' with reliance on Charter rules and procedures. This led the Panel to contend that actions of this kind would set precedents leading to a generalized erosion of the principles of the collective security regime. They warned that,

in a world full of perceived potential threats, the risk to the global order and the norm of non-intervention on which it continues to be based is simply too great for the legality of unilateral preventive action, as distinct from collectively endorsed action, to be accepted. Allowing one to so act is to allow all (United Nations, 2004, 55).

This assessment, however, misses the crucial point that in a post-9/11 world Washington perceives itself to be at once uniquely imperilled and yet the only actor capable of meeting the challenge.

It follows from this that for the Bush administration the crisis of legitimacy can only be resolved through international society's granting of special rights which entitle the United States alone to utilize force in the face of perceived, but as yet nascent, threats. The problem, of course, is that what represents the solution from a US perspective constitutes the problem for those who remain sceptical about US claims of endangerment, concerned by its proclivity to resolve matters through violence, wedded to the exclusive rights of the UNSC, and committed to the existing collective security regime. In short, for these states the US' prescription fails to address the crisis of legitimacy of which they 
now seek resolution. If this were the end of the story, there would be little prospect of reaching an accommodation. However, the unexpected level of the costs that Washington incurred as a result of its invasion of Iraq, and the growing recognition that its military strength offers little in the way of real leverage in its dealings with 'rogue states' such as Iran and North Korea, might lead the administration to invest greater significance in seeking multilateral solutions to global problems.

While these developments bode well for the grand bargain we have outlined, it would be naïve to think that, even in a UNSC comprised of states committed to dialogue, cases will not present themselves in which different assessments of the threat are irreconcilable. This is particularly likely to arise in situations where concerned states are calling for preventive action. The fears generated by the Iranian nuclear programme represent a case in point, and at the time of writing it remains to be seen whether the Council can stay firm to the multilateral route mapped out in Resolution 1696 in a way that was not possible over Iraq (www.un.org/News/Press/docs/ 2006/sc8792.doc.htm). If, for example, a proposal for coercive action in response to Iranian non-compliance with the resolution were to receive majority support in the UNSC but be blocked by the casting of a veto, would legitimacy claims in support of coercion resonate in either international or world society?

Such a situation would reignite the legitimacy contest occasioned by NATO's action in Kosovo where the threat of veto precluded adherence to the edicts of the Charter, but where there was strong evidence to suggest that there was international support that went well beyond the Alliance. The dangers inherent in invoking the 'unreasonable veto' cannot be discounted. It is for this reason, along with the optimism that characterized the time of its writing, that the Charter gives no credence to it. Nevertheless, the essence of the argument that underpins it, namely that procedural determinants cannot deprive an action of legitimacy in the face of strong evidence of support within an international social constituency congruent with the realm of political activity, remains compelling. If the legitimizing grand bargain discussed above can be undermined by the vote of a single state - perhaps cast in furtherance of a genuine view of what is best for international society, but also possibly on the basis of narrowly conceived selfish interests - then it is a highly precarious resolution to the crisis of legitimacy.

The founders of the UN determined that the ultimate goals of the organization must not only be to prevent the resurgence of the major threats to international peace of their day - namely Nazi Germany and Imperial Japan - but also to ensure continuing cooperation among the Great Powers which were both the organization's architects and linchpins. Consequently, they contrived a system in which in the absence of Great Power unanimity, 
institutional inaction resulted. They did so fully cognizant of the fact that in such circumstances this would deprive the UN of its ability to fulfil its primary role in maintaining international peace and security, and of the fact that while Great Power conflict may still ensue, it would be beyond the UN's competence to prevent or subsequently deal with this. In the circumstances of their day this was an understandable stance, but 60 years hence this is less clearly the case. Great Power conflict is no longer commonplace - a result of both the socializing effects of norms and the terrifying prospect of nuclear annihilation - and hence the necessity of a complete brake on action that cannot be shoehorned into the Charter framework is contestable. Where the likely implications for international order fall within acceptable bounds, the substantive good to be achieved is worthy and feasible, and sufficient support is forthcoming to meet the demands of international legitimacy, strict conformity with the voting procedures of the UN Charter can no longer be taken to constitute the defining notion of international legitimacy. Whether the first two of these criteria can ever be assessed - either in advance or in the aftermath of military action - is a matter of intense debate. This is the task that befalls those charged with burdens of state leadership, and as such the determinations they make in this regard are likely in turn to shape the level of support that is the necessary final element of the calculation.

\section{Conclusion}

The fact that hard cases are likely to present themselves is no reason to eschew the crisis resolution model outlined here. We have argued that a bridge has to be built that reconciles the alternative conceptions of the crisis of legitimacy facing the UN Charter regime and the role of the UNSC at its centre. In his Introduction, Reus-Smit develops a theoretical framework which suggests that crises of legitimacy can be ameliorated by either recalibrating social relations or by substantiating a fixed preference through the exercise of material might. Our examination of Council disempowerment suggests that reliance on material levers is at best only a short-term palliative that will lead to progressively greater costs being imposed on those who rely on them. As the case of Iraq shows, even the United States is susceptible to the consequences of diminishing returns. The only long-term solution lies, therefore, in a dialogue that has as its goal the re-empowerment of the UNSC as the cornerstone of a revitalized collective security regime. On the one hand, the challenge is to persuade those who hold a more conservative interpretation of Article 39 to broaden it to enable the UNSC - and hence the collective security regime in which they place such store - to adapt to contemporary threats and, in extremis, to recognize that there might have to be the occasional departures 
from specific Charter procedures as distinct from underlying norms. On the other hand, those who wish to claim special prerogatives in relation to the use of force - whether in the form of humanitarian intervention or preventive war - must recognize that there is a clear relationship between the legitimacy of such actions and the extent of the international social constituency within which they are able to draw support. Invariably this support will be maximized where those seeking to act do so in accordance with the edicts of the Charter. Where the UNSC is divided and it is believed that circumstances exceptionally necessitate the taking of action that circumvents its authority, those who seek to act must be sensitive to the fact that their actions undermine the ideal of collective security and feed the pessimism of those who harbour concerns about the normative capacity of the UNSC to constrain the hegemon.

The Bush administration has to decide in its second term whether it is prepared to invest in multilateral mechanisms of security given its revolutionary predisposition. In the aftermath of the Second World War the United States enjoyed a preponderance of power no less marked than that of today, and yet it invested more heavily than any other state in history in the development of global institutions. It did so because it recognized, understood and valued the existence of a framework within which it could engage - however unequally with the growing membership of international society (Ikenberry, 2001, 2002). In short, the United States understood that whenever and wherever possible, it should ensure that its social constituency of legitimacy should be coextensive with its orbit of political action. Despite the challenging nature of the Cold War years, successive administrations recognized that invariably the policies which most favoured US interests were those which were premised on the observance of law, consensual decision making, moderation and the preservation of peace (Tucker and Hendrickson, 2004). Even for an omnipotent state, the legitimacy that flows from such behaviour is valuable because it enables a state to tap into the 'wellspring of voluntarism' (Reus-Smit, this volume) and hence to reduce the costs associated with coercion and bribery. And for those who reject such a counsel (Kagan, 2004) one salutary note is worth sounding: the one feature common to all of history's Great Powers is their ultimate demise. With this in mind, and understanding that in their constraining nature institutional frameworks serve to protect the weak from the excesses of the strong, it would be prudent for the US to reinvest in global institutions. If a state such as China was to rise to take the place of the United States as the global hegemon - a far from fanciful prospect given current projections of economic growth - the values which Washington and its allies currently champion as being universal may seem far from that. In such circumstances many of today's naysayers may be inclined to look more positively on an international normative regime embedded in a truly social conception of legitimacy. 


\section{References}

Annan, K.A. (2003) 'The Secretary General Address to the General Assembly, New York, 23 September 2003', www.un.org/webcast/ga/58/statements/sg2eng030923.

Barber, B.R. (2003) Fear's Empire: War, Terrorism, and Democracy, New York: Norton.

Blair, T. (2004) 'Full Text: Tony Blair's Speech', http://politics.guardian.co.uk/iraq/story/ 0,1162991,00.html.

Blix, H. (2004) Disarming Iraq: The Search for Weapons of Mass Destruction, London: Bloomsbury.

Buchanan, A. and Keohane, R.O. (2004) 'The Preventive Use of Force: A Cosmopolitan Institutional Proposal', Ethics and International Affairs 18(1): 1-23.

Chesterman, S. (2001) Just War or Just Peace? Humanitarian Intervention and International Law, Oxford: Oxford University Press.

Clark, D. (2003) 'Iraq has Wrecked Our Case for Humanitarian Wars', The Guardian, August 12, www.guardian.co.uk/comment/story/0,3604,1016573,00.html.

Clark, I. (2005) Legitimacy in International Society, Oxford: Oxford University Press.

Claude, I. (1966) 'Collective Legitimization as a Political Function of the United Nations', International Organization 20(3): 267-279.

Claude, I. (1984) Swords Into Plowshares: The Problems and Progress of International Organisation, New York: McGraw-Hill.

Evans, G. (2004) 'When is it Right to Fight', Survival 46(3): 59-83.

Fassbender, B. (1998) UN Security Council Reform and the Right of Veto: A Constitutional Perspective, The Hague: Kluwer Law International.

Feinstein, L. and Slaughter, A.-M. (2004) 'A Duty to Prevent', Foreign Affairs 83(1): 136-150.

Franck, T. (1990) The Power of Legitimacy Among Nations, Oxford: Oxford University Press.

Frum, D. and Perle, R. (2003) An End to Evil: How to Win the War on Terror, New York: Random House.

Glennon, M. (2003) 'Why the Security Council Failed', Foreign Affairs 82(3): 16-35.

Goodrich, L.M. and Hambro, E. (1949) Charter of the United Nations: Commentary and Documents, Boston: World Peace Foundation.

Hassner, P. (2002) 'Definitions, Doctrines and Divergences', The National Interest 69(Fall): $30-34$.

Hendrickson, D.C. (2002) 'Toward Universal Empire: The Dangerous Quest for Absolute Security', World Policy Journal 19(3): 1-10.

Henkin, L. (1979) How Nations Behave: Law and Foreign Policy, New York: Columbia University Press.

Ikenberry, J.G. (2001) After Victory: Institutions, Strategic Restraint and the Rebuilding of Order after Major War, Princeton: Princeton University Press.

Ikenberry, J.G. (2002) 'America's Imperial Ambition', Foreign Affairs 84(5): 44-60.

Jackson, R. (2000) The Global Covenant: Human Conduct in a World of States, Oxford: Oxford University Press.

Jervis, R. (2006) 'The Remaking of a Unipolar World', Washington Quarterly 29(3): 7-19.

Johnstone, I. (2003) 'Security Council Deliberations: The Power of the Better Argument', European Journal of International Law 14(3): 437-480.

Kagan, R. (2004) 'Renewing US Legitimacy', Foreign Affairs 83(2): 65-88.

Kaplan, L.F. and Kristol, W. (2003) The War over Iraq: Saddam's Tyranny and America's Mission, San Francisco: Encounter Books.

Kissinger, H. (1977) A World Restored: The Politics of Conservatism in a Revolutionary Era, London: Victor Gollancz.

Lowe, V. (2003) 'The Iraq Crisis: What Now?' International and Comparative Law Quarterly 52(4): 859-871. 
Malone, D.M. (2006) The International Struggle Over Iraq: Politics in the UN Security Council 1980-2005, Oxford: Oxford University Press.

Morris, J. (2000) 'UN Security Council Reform: A Counsel for the 21st Century', Security Dialogue 31(3): 265-277.

Morris, J. (2005) 'Law, Power and Force in an Unbalanced World', in R. Burchill, N.D. White and J. Morris (eds.) International Conflict and Security Law: Essays in Memory of Hilaire McCoubrey, Cambridge: Cambridge University Press, pp. 286-313.

Murphy, S. (2004) 'Assessing the Legality of Invading Iraq', Georgetown Law Journal 92(2): 173-257.

National Security Strategy (2002) September 20, www.whitehouse.gov/nsc/nss.html.

National Security Strategy (2006) March, www.whitehouse.gov/nsc/nss/2006/.

Reus-Smit, C. (2004) American Power and World Order, Cambridge: Polity Press.

Roberts, A. (2003) 'The UN Will Survive this Storm', Observer, March 9.

Russell, R.B. (1958) A History of the United Nations Charter, Washington, DC: Brookings Institute.

Sands, P. (2005) Lawless World: America and the Making and Breaking of Global Rules, London: Allen Lane.

Simpson, G. and Wheeler, N.J. (2006) 'Preemption and Exception: International Law and the Revolutionary Power', in T.J. Biersteker, P.J. Spiro, C.L. Sriram and V. Raffo (eds.) International Law and International Relations: Bridging Theory and Practice, London: Routledge, pp. 11-26.

Tesón, F.R. (2005) 'Ending Tyranny in Iraq', Ethics and International Affairs 19(2): 1-20.

Tucker, R.W. and Hendrickson, D.C. (2004) 'The Sources of American Legitimacy', Foreign Affairs 83(6): 18-33.

United Nations (2004) A More Secure World: Our Shared Responsibility, Report of the High-level Panel on Threats, Challenges and Change, UN GAOR, 59th Sess., Supp. No. 565, UN Doc. A/59 (2004), www.un.org/secureworld/report.pdf.

Wheeler, N.J. (2000) Saving Strangers: Humanitarian Intervention in International Society, Oxford: Oxford University Press.

Wheeler, N.J. (2004) 'The Humanitarian Responsibilities of Sovereignty: Explaining the Development of a New Norm of Military Intervention for Humanitarian Protection in International Society', in J. Welsh (ed.) Humanitarian Intervention and International Relations, Oxford: Oxford University Press, pp. 29-52.

Wheeler, N.J. (2005) 'The Dangers of American Exceptionalism in a Revolutionary Age', in M. Gurtov and P. Van Ness (eds.) Confronting the Bush Doctrine: Critical Views from the AsiaPacific, London: Routledge, pp. 181-203.

Wheeler, N.J. and Morris, J.C. (2006) 'Justifying Iraq as a Humanitarian War: The Cure is Worse than the Disease', in W.P.S. Sidhu and R. Thakur (eds.) The Iraq Crisis and World Order: Structural, Institutional, and Normative Challenges, Tokyo: United Nations University Press, pp. 444-463.

White, N.D. (1993) Keeping the Peace: The United Nations and the Maintenance of International Peace and Security, Manchester: Manchester University Press. 